\title{
PHANTOM REBELLION: PERFORMING THE STATE IN A MONTENEGRIN VILLAGE AND BEYOND
}

\begin{abstract}
The article describes an event in Njeguši, a small village in Montenegro, whereby a group of people tried to honour their ancestor and inaugurate a commemorative building. Unexpectedly, the event was forbidden by the authorities, and the police appeared ostensibly to prevent the outbreak of violence between church factions. I use this ethnographic case as a window to examine how the state comes into being using the concepts of 'phantom' and 'performance', where phantoms are defined as things and people that once used to be or that were imagined and treated as a real threat or support and therefore caused actual events. I argue against pathologizing the illusory quality of the state, but instead demonstrate that phantoms are formative and inevitable part of what the state is and how it is performed. Instead of passively reacting to such phantoms, participants can form active alliances with them in order to perform the kind of state that they prefer. The resulting performances are not uniform; various actors may act in a contradictory manner, the same phantoms may be treated as friends and foes depending on perspectives. Yet collectively, the alliances with phantoms contribute to the same result-the emergence of a state.
\end{abstract}

Keywords: State, Balkans, Performance, Phantoms

We were followed everywhere by Njegos.. (Although it was just an optical illusion of a spirit, we thought he was following us,

but in fact we carried him). Yes, we were followed by him everywhere. But his living and life-giving presence we felt at all times during the epoch of our greatest national and social cataclysms. (Ivo Andric, quoted from http://www.njegos.org/petrovics/andric.htm, edited for readability by me)

The phantom limb is perceived as perfectly real to the patient, who describes it as being in various positions and often reports feeling pain in it. (Melzack 1992: 121) 


\section{INTRODUCTION TO A PHANTOM ${ }^{1}$}

The house was cold and humid and, apart of occasional spiders, empty of inhabitants when we moved in. After my wife and I had lived there a couple of days, Milan ${ }^{1}$, the owner of the house paid us a visit. He used to live here with his family, but it was mostly during the summer months. That is why the wood stove had been removed, leaving only a spot where it once used to stand. The hole in the wall where the chimney once stood was now covered with a tin lid. One of the rooms was filled with old matresses and other unused bedclothes. On the wall was an old photo of a couple-a stern-looking man and his wife who was nearly his height, both staring into the eye of anybody who entered the room. Milan insisted that while the house was empty, certain defensive measures would be needed in order to keep out any invaders: flies would be abundant here during the summer, he insisted. Consequently, Milan spent half the day blocking out our windows with an anti-fly mesh. I helped by passing him the hammer and nails and holding the ladder. A similar mesh had to be put on a small tube that led the condensation water from between the window frames. 'The spiders could enter through here' he explained. We sat down and my wife offered to prepare Turkish coffee for all of us ('Six spoons of sugar for me, please' instructed Milan). While I was sipping my coffee, wondering if six spoons can physically be dissolved in the tiny cup of coffee, Milan said: 'Do you know that you live in the house of the guvernadur Radonjić?

That is how I was introduced to one of the phantoms that lived in seemingly uninhabited places and houses of Njeguši, a small village in Montenegro. In this village, which itself could be described as partly a phantom, people were scarce, but different kinds of phantoms were abundant. In fact, there were whole armies of phantoms which stood ready to make their move at the right moment.

I use word 'phantom' here to indicate objects and people that once used to be present, or that were imagined and treated as being present: either as a threat or as a support. In this sense, phantoms were agents: they could provoke or contribute to observable events. My use of the term 'phantom' is similar to Avery Gordon's interpretation of the ghost. For Gordon,

The ghost (...) is not the invisible or some ineffable excess. The whole essence (...) of a ghost is that it has a real presence and demands its due, your attention. (Gordon 2008: xvi)

Phantoms are not necessarily humanoid in form; they could also be animate or inanimate, objects, living or dead animals as well. The spiders and flies that Milan wanted to protect us against were examples of such phantoms: they were not there, and they never materialised, but nevertheless, we worked to build defences against them. Out of all the phantoms that I met in Njeguši, I pay closer attention to two: those of guvernadur Radonjić and vladika Njegoš. Both used to be local leaders, but they gained strength from the armies that they once led. Describing the role of these two phantoms will be used as my attempt to understand the phenomenon of the state. Other imagined things or creatures (like insects, or a missing eye or even absent pigs) simply illustrate that what I am talking about in relation to the state, is not an isolated phenomenon.

Phantoms are not necessarily malevolent and people can do more with them than just be afraid or flee from them. One can summon phantoms in an attempt to assert oneself in a social conflict or political struggle. The concept 
of the state in this sense is a phantom itself as it is at the same time elusive to academic scrutiny (Abrams 2006) and so real that it governs people's minds and actions, mobilising them, causing conflicts or facilitating friendly cooperation. Guvernadur Vukolaj Radonjić, with whom we apparently shared living quarters during the time of my stay in Njeguši, materialised and participated in a rebellion which itself was nothing more than a phantom.

In this article, I argue that people in Njeguši, as well as elsewhere perform the state by invoking and interacting with such phantoms. People make conscious decisions about alliances with particular phantoms. I argue, therefore, that phantoms are not simply imaginary escapes from reality, but that they help to form the actual content of state practices. Phantoms are part of the process through which the state is performed.

In the following text, I first introduce Njeguši, the village in Montenegro where the events described here took place. I then outline the two central concepts in my argument: the state and performance. After that I proceed to giving more substantial information on Guvernadur Radonjić and the historic and contemporary background to the events that I call phantom rebellion, describing the event itself in the context of state performance. I then discuss the concept of phantom in relation to the state. I conclude with arguing that phantoms are central and formative to the state and are inevitably part of the process of state performance.

\section{THE VILLAGE}

In 2017, I spent four months in Njeguši, a small village in Montenegro. The village can be reached by car in about 40 minutes from either of the closest towns-Kotor, which is located on the shores of the Adriatic or the old royal capital of Cetinje, which lies more inland. Either way, the road is winding and at times perilous. It leads to the plain of Njeguši, which is approximately $800 \mathrm{~m}$ above sea level, surrounded by mountain peaks as high as $1749 \mathrm{~m}$. During the time I spent in Njeguši, I spoke to approximately 70 people which is about half the total number of permanent inhabitants. According to official statistics, there have never been more than 77 inhabitants of the village, while in the last two censuses (2003 and 2011) there were only 17 and 35, respectively-a fact that speaks about the counting methods more than about the actual fluctuations of the population. The elderly inhabitants whom I interviewed recalled times (referring to their childhood some 40 or 50 years ago) when several thousand people used to live in Njeguši.

The village itself consists of eight separate settlements. Of these, two are completely abandoned. A third is inhabited only when people who live elsewhere arrive there to spend holidays and the remaining five settlements are in various levels of abandonment. There are two large school buildings, both now closed; one them still has a roof and most of its doors and windows, while the other one has lost part of its roof and is now home to the neighbours' hens and goats as well as a pack of stray cats. These eight settlements have no less than 14 Orthodox churches, eight of which are somehow maintained. Services are sometimes held in these churches, and three of them have been comparatively recently renovated and redecorated. The rest are again competing for the dubious honour of the one that would collapse the first. In the two most populated settlements (Erakovići and Raičevići) only about a third of the houses are inhabited, which is much more than in other parts. Njeguši, in a manner of speaking, is a village full of phantom inhabitants and phantom homes. 
This, however, is not the whole story. The remaining inhabitants are busily engaged in a rather booming production of local homemade specialities: smoked ham (pršut), cheese, wine, and grape brandy rakija, all of which are actively traded either directly or through one of the eight restaurants catering to the tourists who pass though Njeguši in the summer season. The number of hams produced according to the members of the association of local pršut producers is at least 100000 yearly with the capacity of almost 200000 (a piece of ham being the complete upper hind leg of a pig). The raw meat is not produced locally but imported from various EU countries (e.g. Spain or the Netherlands) or from neighbouring Serbia. Tourists, however, were sometimes told that the herds of pigs were being kept right there, above Njeguši in the mountain pastures and that the ham was purely a local product.

Das and Poole (2004:3) and NavaroYashin (2002:165) have argued that it is the marginal places where the building blocks of the state are most visible. This is also the case with Njeguši. The village's two school buildings were crumbling, the police were far away in the towns, the closest state institution was a post office that was now half-converted into a private souvenir shop. The local registrar, whose job was to record key life events such as births, deaths and marriages, had an office in one of the dilapidated school buildings. But with so few inhabitants, any of these kinds of events occurred only rarely these days, so most of the time the registrar's office was closed. Fearing drive-by hooligans, the registrar employed a kind of a phantom security guard, keeping the office lights on day and night in the hope that this scarecrow-style tactic would prevent the windows from being smashed.

So, what and where was the state of Montenegro in Njeguši? The story surrounding the phantom rebellion is an attempt to illustrate the subtle movements and choices that constitute the process of state performance. The apparent absence of the state, what Goldstein (2012) calls a 'phantom state' was part of what the state was in the village of Njeguši. At one point in this story, when the phantom army of guvernadur Radonjić appeared on the scene, as I will show, the state became much more directly constructed, it coagulated and became almost palpable.

\section{THE PHANTOM OF THE STATE}

Current understandings of the state have emphasized the state as illusion or an abstract idea. Such an approach towards the state is hardly new. It goes back to at least the writings of Marx and has been in various ways employed (implicitly or explicitly) by thinkers who have written about the state or processes related to the state ever since (e.g. Radcliffe-Brown, Foucault, Althusser, Abrams, Mitchell, Taussig). The concept of illusion and fantasy inevitably begs to be contrasted with the reality. If something is an illusion, it cannot be real. Describing something as an illusion therefore requires some kind of unmasking exercise, the ultimate goal being the destruction of the illusion. RadcliffeBrown's denunciation of the state as 'a fiction of philosophers' (Radcliffe-Brown 1987: xxi), is rooted, according to Taussig, in RadcliffeBrown's aversion to the insubstantiality of political power (Taussig 1992: 113). For a similar reason, Taussig himself writes about the state as a fetish. Abrams, arguing that the state is an illusory concept, concludes that the state is an idea that serves as a mask that conceals the actual political process (Abrams 2006). Drawing on Žižek's Lacanian analysis of the ideology of the state (Žižek 2008), Navaro-Yashin agrees that the state is an illusion and argues that citizens 
are well aware of the state's illusory character (Navaro-Yashin 2002: 161). Nevertheless, they carry on behaving as if they did not know that, in other words, they are acting cynically. Lacan and Žižek qualify this cynicism as a symptom, that is to say a sign of pathology. According to the principles of psychoanalysis, revealing the causes of a condition should stop the patient from continuing the pathological behaviour. But the citizens carry on with their sickness willingly 'in full consciousness of their counterproductive (or self-destructive) quality' (Navaro-Yashin 2002: 162). Navaro-Yashin uses the concept of fantasy by which she means a 'symptom that survives analysis, critique, or deconstruction' (Navaro-Yashin 2002: 4).

This line of reasoning pathologizes both the state and the individual's belief in its reality. It implies that once the illusion is discarded, people would somehow be liberated and live better lives. Although I can accept such an approach as a part of political debate, as an anthropologist I find describing a common human condition (belief in the reality of the state) as a symptom or pathology, fundamentally problematic. Therefore, following Jansen's (2014: 20) suggestion, I treat the illusory quality of the state not as a pathology, but as an inevitable element of the state.

Religion can be used as a helpful analogy, especially because the state is often described in religious terms (see, for instance, Taussig 1997; Taussig 1992). Religion, too, is a phenomenon connected with fantasy and as such has been denounced as antithetical to reason (as Marx's 'opium of the people', Freud's 'mass-delusion' or simply as rooted in 'belief') and thus as a curiously persistent pathology. However, a more productive way of looking at religion is by recognising it as a part (and not a by-product) of the normal way of thinking. Bloch argues that the capacity to treat reality not only on the basis of one's direct immediate experiences is a feature specific to human mind. While trying to explain why humans 'hold such ridiculous ideas as: there are ghosts that go through walls; there exist omniscients; and there are deceased people active after death' (Bloch 2013:24), Bloch argues that 'the capacity to imagine other worlds (...) is the very foundation of the sociality of modern human society' (Bloch 2013: 25). Accordingly, people treat each other not only on the basis of what they have actually experienced in one-to one interaction, but also on the basis of more abstract social roles. Encountering a police officer on the street, I do not interact with just 'a person'. I interact with a 'police officer', about whom I have certain expectations. Somehow similarly to Bloch, Ivy uses the concept of 'phantasm', stating that all events are experienced only after the act in a repetition that becomes its own spectral origin' (Ivy 1995). Thus, what is experienced is always only a 'phantasm' (i.e. an illusion or a ghost). Quite along the same lines, Derrida concludes that the 'phenomenal world itself' as well as the 'phenomenological ego' is a spectre (Derrida 1994: 169). Consequently, fantasy is a part of the way we perceive the social as well as the physical world. In this sense fantasy and its fruits cannot be separated from 'reality'.

Is 'reality' liberating? Would we somehow be liberated after learning about the illusory qualities of our world? I believe that this view is naive in the context of the fact that the world as it is perceived (with colours, sounds, relationships and meanings) exists only because of our brain functions. While it is important to distinguish the role of illusion and fantasy in the way we experience the world, one cannot expect that knowledge of that construction would somehow change the way people live their lives (unless of course they have a pathological condition, in which case their world may indeed 
crumble). Hence, what Navaro-Yashin describes as 'fantasy', what she treats as the next level in accepting illusion and therefore as a symptom and cynicism, may be a part of normal mental processes. Fantasy is part of our everyday life.

\section{THE PERFORMANCE OF THE STATE}

The state, then, is a complex abstraction under the umbrella of which one can enumerate various activities and expressions (like bureaucratically organised processes, the particular power structures and relations, written and unwritten laws, principles and values related to these processes, resulting, for instance, in what is called the 'welfare state' and other institutions). By means of imagination, these and other elements are held together in the concept of the state. At times and often powerfully, the state seems to be a living being, a person capable of a full spectrum of activities and emotions (even scholars fully aware of this illusion are not spared of it). However, the way this whole process is carried out, the actual, observable activity of the state, requires it to be performed.

The idea of seeing the state through the lens of performance is not new in anthropology. Thus, for instance, Yurchak (2006), analyses the performative aspects of late socialism and particularly the Soviet state. In doing so, Yurchak draws on Austin's idea of constative and performative utterances. But in contrast to Austin, Yurchak seems to give preference to constative over performative utterances in relation to the state. Hence, Yurchak treats the performativity of the Soviet state as a critical aspect that distinguishes it from other states and from earlier version of socialism (see, for example, Yurchak 2006: 24-25).

In contrast to Yurchak, I see performativity as an integral part of all states at all times. Like
Yurchak, I draw on Butler's analysis of gender as a result of performance. Curiously, Butler writes that her idea of the performative nature of gender comes from Derrida's analysis of Kafka's description of the state, 'Before the Law' (Butler 2006: xv); thus, the idea of performance makes a full circle here, originating and ending with the state. According to Butler, the gendered body 'has no ontological status apart from the various acts which constitute its reality' (Butler 2006: 185). If the state is a phenomenon that comes into being similarly to gender (i.e. through performance), then states also have 'no ontological status' apart from these acts. My reading of performance emphasises not only individual acts, utterances and gestures, but also interaction with and on behalf of the spectators who, as in all performances, become part of the act. Thus, a state is a result of multiple simultaneous, repeated acts and the audience's interpretations of such acts. Participation in the performance process is just as important as avoiding participation; working for a goal is just as important as trying to sabotage the process. When seen in this light, the state can be perceived as a collective result of acts that are simultaneously performed by each and every participant in the state processes. In this sense, my approach is similar to that of Navaro-Yashin when she emphasises, for the same reason, the multiplicity of actors involved in the state and the lack of particular places where one should seek out the state (Navaro-Yashin 2002: 2-3). Moreover, the actual performances and interpretations of these performances include various kinds of imaginative processes, among which are the phantoms which I will discuss in more detail below.

Such an inclusive interpretation of state performance differs from interpretations that limit state practices to performances by 'state actors'. For instance, Bobick (2014) draws on 
examples from territories such as Transnistria to argue that state-like entities gain legitimacy through state-like performances. Similarly, Bissenova (2014) and Laszckovski (2014), demonstrate how the state is performed through construction works that produce the image of the state. There is also an analytical problem in this approach, as one needs to first be able to define what the state is and who are the people and actions that constitute the state. Only then one can speak of what performances these actors or groups do. Therefore, at the same time and in the same settings, Bissenova demonstrates that state performance involves all people-those who plan and finance the construction works as well as those who are simple workers, but who draw pride from being a part of the process.

The state is thus performed and actively invoked not only by the ruling elites. Also involved are performers at ground level: the ordinary people who play their role as citizens or as state agents, regardless of whether they are so authorised by the vertical power structures or not. These kinds of processes have been described in highland Georgia (Mühlfried 2014) as well as in Central Asia (Beyer 2014; Ismailbekova 2014; Bissenova 2014) and Latin America (Jusionyte 2015). Not to be forgotten here are various subversive and evasive acts, such as corruption, criminality or tax evasion. These are also part of the state performance because only with these elements in sight can the full picture of the state be grasped. This approach to the state allows us to refrain from making normative evaluations (such as categorizing some states as (failed') and to instead consider what is actually happening. There is a certain dynamic between various versions and interpretations of the state. Thus, for instance, tax evasion or organisation of economic activities along kinship lines may be seen by participants or bystanders as either antithetical to the state or as having nothing to do with it. The analytical framework that I propose here, however, includes all these practices as well.

Since there are many different perspectives, the performances will be far from uniform and there is no single coherent state performance. Referring to the ethnographic works quoted above, one manifestation of state is performed through the actions of a bureaucrat while quite another state will be performed by a construction worker. Nevertheless, both contribute to the same result-the state. Let us therefore return to the village of Njeguši in the highlands of Montenegro to see how phantoms contribute to state performance.

\section{THE LAYOUT OF THE PHANTOM BATTLE}

'There are vaults under there' Milan said, pointing to the concrete-covered yard in front of our small yellow house. 'Our houses here in Njeguši are very special, nobody else has the vault-on-top-of-thevault (volat na volat) technique used for the houses except here and in Kotor. Did you see the cellar under the building? [I had seen it, all different kinds of old stuff were stored there in case of a need] That's it. But there, underneath that yard, there are more. Archaeologists say so, but it is not yet explored.'

Currently, though, the yard was used as a small car park. Željko, Milan's cousin, introduced me further to the place and explained more about guvernadur Radonjic's legacy. 'Here was the old entrance to the compound', he told me, showing a gate that resembled the entry to a small castle. We passed by the gate, turned right and found ourselves in a small piazza paved with stones. On the one side of this square was a tiny chapel 
and on the other end was a house that was clearly renovated so that it could have been inhabited. The chapel, the house and the square itself had all been freshly refurbished; the stones had not yet turned grey, as normally occurs with the old buildings, but were of old ivory colour. Željko unlocked the door and led me into the house. Inside was a single large room with a long wooden table in the middle, stools on both sides. A half-empty bottle of rakija was on the table along with a couple of small glasses. On the far wall of the room hung a portrait of a man in ancient robes. His left hand held a rifle over his shoulder and his right hand was resting on a handle of a pistol that was stuck behind his wide silk belt. 'That is Vukolaj Radonjić' said Željko. 'The guvernadur'.

Apparently, the building was arranged to commemorate the famous ancestor of Željko. In Željko's own genealogy that he recounted to me, and which altogether contained about 80 persons in 4 generations, Vukolaj did not appear. But this mattered little, because according to Montenegrin understandings of relatedness, all people who share the same surname and come from the same village can be considered of the same blood. They recall their origins from the same single founding ancestor and are thus considered to be related, even though not everyone knows the exact genealogical connection.

In my subsequent encounters with Željko and others from the Radonjić family, I acquired details of the sad story of the guvernadur Vukolaj Radonjić, but since the story was always positioned on the background of the more conventional Montenegrin official history, I must sketch that story first.

\section{THE STORY OF GUVERNADUR VUKOLAJ RADONJIĆ}

The Montenegrin story of post-Ottoman history usually starts with the times of prince-bishops (vladika) $\left(16^{\text {th }}-19^{\text {th }}\right.$ century). These were local orthodox bishops who possessed both spiritual and secular powers. Although the version of history taught in schools and displayed in museums emphasizes that Montenegro was never occupied by the Ottomans, the actual situation is sometimes disputed. In any case, the local non-Muslim 'people of the Book' (whose faith, according to the Quran, was nevertheless recognised by the Muslim overlords as legitimate) were governed through local spiritual leaders according to the millet system generally employed by the Ottoman Turks in Christian lands (Benjamin and Lewis 1981). The first vladika was elected by the common Montenegrin meeting ( $z$ bor) in 1516. From the late $17^{\text {th }}$ century, the position of vladika was almost exclusively held by representatives of the Petrovic lineage, with roots in the village of Njeguši. Because the bishops were not allowed to marry, the transfer of power was mostly to a brother's son, but elections were still held in order to confirm the new ruler. The last in the line of the great vladikas was Petar II Petrović Njegoš, commonly known simply as Njegoš. When he died in 1851, he was succeeded by his nephew Danilo, who, not wanting to lead the life of a celibate monk, established himself as a secular duke (knjaz), thus ending the vladika era. When Danilo was assassinated by a fellow Montenegrin from another tribe, the dukedom was inherited by Danilo's nephew Nikola, who ruled for 58 years (1860-1918). In 1910, Nikola became a king of Montenegro, but in 1918 Montenegro lost its independence in a disputed referendum to join the newly created Kingdom of Serbs, Croats and Slovenes (later 
Yugoslavia). After World War II, Montenegro remained one of the federal republics of the socialist Yugoslavia and was the last to exit the rump state in a 2006 referendum. In the last twenty years, Montenegrin politics has been the most stable, and stagnant, as it has been dominated almost singlehandedly by a single individual: Milo Đukanović, who entered the political scene in late 1980s as the young and promising reformist communist. After having been six times prime minister, Đukanović is now serving his second term as president (for a detailed insight see Bieber 2003). ${ }^{2}$

What is important for our story is that the birthplace of the Petrović-Njegoš dynasty and many of the rulers is the village of Njeguši, specifically the settlement of Erakovici. There is a commemorative museum in the centre of Erakovići-'The Native House of Njegoš' (Muzej Njegoševa rodna kuća). Next to this comparatively humble stone building stands another one which was used by King Nikola as a country retreat. King Nikola was also born in the same house as Njegoš. Overlooking the village are several high mountain peaks, the second highest being Jezerski Vrh (1657 $\mathrm{m})$. Atop this mountain lies a monumental mausoleum surrounding the grave of Njegoš. The mausoleum is visible from almost any vantage point in the village during the day and sometimes at night as well. Njegoš himself is praised not only as a politician and military leader but also as a literary genius. His works form a significant part of the classical SerboCroatian literary canon. His picture was on a series of Yugoslav paper bank notes (abandoned in Montenegro in 2002, when it unilaterally adopted the Euro as official currency). Thus, Njegošs presence is intensely visible in Njeguši, and the entire layout reinforces this particular version of the Montenegrin state and its history. People in Njeguši and in much of Montenegro, from where the mausoleum is visible (because of its mountaintop location), are virtually followed by Njegoš, as expressed in the introductory vignette above.

The dynasty of Petrović Njegoš is the bedrock of the official history of Montenegro. The problematic aspect, however, is that the last of the kings, King Nikola, lost his power and was forced to emigrate to Italy. I had read this story in many versions in history books, heard from guides in museums and from many people who were eager to enlighten me with details of Montenegrin history. On this background, I was little prepared to hear the kind of story that my new hosts in the neighbouring settlement of Raičevići were telling me.

According to Željko and his relatives, the Petrovićs were not the only dynasty in Montenegro at the time of vladikas. Parallel to the vladikas was also another inheritable position, that of guvernadur (governor) who was a secular ruler and at times the only centre of the power in Montenegro. The post of guvernadur existed from the early years of the $18^{\text {th }}$ century and ended in 1832 with the death of Vukolaj Radonjić. Initially a representative of Montenegro to Venetian republic, the guvernadur at times became an important force in seeking Montenegro's independence, I was told, participating in or leading the running of the country. However, a conflict eventually emerged regarding ideas about Montenegro's foreign alliances, with the vladika (represented by the Petrović family) and guvernadur (represented by Radonjić family) taking different sides. Petar II Petrović believed that a tighter association with Russia was the most viable strategy, while Vukolaj Radonjić, the guvernadur, felt that Montenegro should forge a closer alliance with Austria. Eventually, the conflict led to guvernadur Vukolaj Radonjić being arrested, thrown into a cell where he got 
ill and died shortly after his release in 1832 in Kotor, which at the time belonged to AustriaHungary.

In the stories told by the contemporary descendants of the Radonjić family, Njegoš was unquestionably a villain, busy enriching himself and his family, establishing himself as ruler while his relatives gained favourable business deals and positions.

Guvernadur Vukolaj Radonjić and the whole Radonjić family, according to the descendants, was on the contrary portrayed as being in favour of closer integration with the European Austria-Hungary.

The official Montenegrin historiography hardly mentions the position of guvernadur. Morrison, for example, in what is otherwise a comprehensive history of Montenegro, devotes but a single paragraph to Vukolaj Radonjić (2009: 23). Nor could I find a single mention of the guvernadur institution in the Montenegrin history museum in Cetinje. The official interpretation as well as some sense of what was happening in 1832 in Njeguši can be deciphered from a description of events are described by the Russian ethnographer Pavel Rovinski, published in 1881:

If you look carefully at this mixture of rock and houses, you would see ruins of some large building. This used to be the house of the guvernadur which is linked with a whole story. A long time ago, the Venetians established the position of guvernadur, as an intermediary between them and the Montenegrin vladikas. (...) The governor was usually from the local family of Radonjićs. Austria decided to turn them into its own agents, and using Austria's support, they started acting with great authority: often not only intriguing against the Montenegrin authority, but also often simply undermining the spiritual authority's [i.e. vladika's] orders, attempting to grab all power to themselves, instigate the people against him and bringing disagreements among the Montenegrins. But their main aim was to make the people to recognise subordination to Austria. This was in the time of vladika Petar II.

When the people had exhausted all their patience and saw where all this would lead, they rose up, surrounded the hated house and when the inhabitants did not want to surrender, they put it to the torch. Later on, some of this family were killed, others saved themselves by running to Kotor, where they still live by the surname of Guvernadurovići.

Thus, the eagle's nest of defenders of Serbdom against the Turkish yoke nearly became a nest of traitors who were preparing Montenegrins for the Austrian yoke. (Rovinski 1881:389-390, my translation from the Russian)

Somewhere in what used to be the ruins of some large building' was my small yellow house, and that of my neighbour Željko as well as other relatives of his. Somewhere nearby was the commemorative room of this same guvernadur Vukolaj Radonjić, who had been arrested and his relatives killed or forced to flee under accusations of betrayal.

The way this story was told by contemporary Radonjićs had direct parallels with contemporary politics, an aspect which they did not fail to mention. They prided themselves on being in opposition to the current government. Like many people with whom I have spoken over the last decade in Montenegro (which has been headed by the same man-Milo Đukanović 
and his Democratic Party of Socialists), they interpreted allegations and rumours of the way the family of the prime minister and his sister and brother have divided powers and earned illicit income as very similar to the way vladika Petar II Petrović Njegoš and his brother were using their power to enrich themselves. The resulting narrative was one of continuity from the past, often concluding with the platitude that 'this is how things have always been done in Montenegro'. Being critical of such a situation in the country, the contemporary Radonjićs often found some relief in promoting an alternative history. This version had much less attraction than the move to forge closer ties with Russia. ${ }^{3}$ Western Europe (as epitomised by Austria in the $19^{\text {th }}$ century and now the European Union) was to be the role model, the natural and proper ally of Montenegrins. Through this vision, Radonjićs were able to imagine the kind of Montenegro that they would have liked to be part of, but which did not exist. Thus, like their ancestor who lived more than 150 years ago, the Radonjićs saw themselves as being in the same struggle against the same adversaries. Hence, guvernadur Vukolaj Radonjić could once again be summoned to lead his forces against his enemies.

The other side, however, was populated with much more powerful phantoms. Njegoš and the Petrovic dynasty in general are a part of the official Montenegrin history. Njegoš himself has been such a powerful cultural icon that virtually all powers that ruled the country since his death have tried to recruit him as their ally-including even the fascist Italian occupation forces during World War II and the communists of Socialist Yugoslavia. The communists even financed a monumental mausoleum on the top of Jezerski Vrh featuring a shrine and a 28-ton granite statue for this priest-aristocrat (Gregović and Kadić 2013).
In the village of Njeguši, where he was born, the link between the people, the state and the story of Njegoš is much more palpable and direct than in the rest of the country. The entire Petrović dynasty originated here. Currently only a single elderly couple of the Petrović lineage (bratstvo) still resided in the settlement of Erakovići. However, there are numerous families of the related Popović family-all of whom take a certain pride in being directly related to the famous ancestors. Đorđe Petrović, on my first visit, took me to the dining room of his home and allowed me to take a photo of him and 'all his ancestors' (as he explained pointing to the pictures on the wall). Coincidentally all the photos were of rulers of the dynasty. It is not uncommon to see portraits of the dynasty prominently displayed in apartments of people in Njeguši-regardless of their relatedness to the royal family. One of the villagers, a hardworking stone mason, has sculpted a head of Njegoš and arranged it as a fountain that supplies a small fish basin with water. Another man, who has a wood-carver's workshop and exhibition near the central piazza of the village, has several scenes of Njegoš depicted in his wooden reliefs. The already mentioned museum building is surrounded by other monuments that remind visitors of this important figure or his close kin.

To sum up, two alternative narratives were competing in the village. Both stories centred on the origins of the contemporary state and linked the villagers to the state in a quite embodied manner-through their kinship ties. The Petrović Njegoš dynasty version of history is unquestionably dominant and is very much integrated into contemporary official historiography, while the narrative of guvernadur Radonjić is an alternative, almost completely invisible in the general story of Montenegro. However, this contesting narrative is a point of significance and purpose for 
a smaller fraction in the village and explains their particular place in the state.

\section{PHANTOMS IN ACTION}

So far, this story of Radonjić family venerating guvernadur Radonjić, is almost merely one of family history, people invoking a past in their everyday lives, commemorating the great ancestors. Invoking their ancestors certainly fills the descendants with some sense of pride. It might inspire them and help form their identity. Njegoš and Vukolaj Radonjić stand symbolically for certain political attitudes and provide legitimacy for the political positions. However, eventually the things in the village demonstrated that the phantom armies (consisting of the leaders detailed above and their followers) in fact have a potential of actual expressions in real struggles.

A group of Radonjić family members eventually started working on an idea of creating a commemorative and informative centre in the village specifically about the guvernadura: both the institution itself as part of the history of Montenegro and the actual persons who held the office, including, of course, the lineage of Radonjić. The aim of this project was to carve out a space for the lineage in the historical narrative so far monopolised by the Petrović dynasty. In order to do that, several activist cousins of the Radonjić lineage, established a foundation aptly named 'Guvernadura Radonjić'. This organisation had collected money and (by means of active physical involvement of the members) had reconstructed two buildings-the small church of St. Archangel (sv. Arhandela Mibaila) and the commemorative house of guvernadur Vukolaj Radonjić that I have already described above.

The church (built around 1700) (Radonjić 2017 ) is perhaps one of the smallest churches in the village and had been in miserable condition before being reconstructed. It was not used as a church for perhaps 50 or so years, at times being adapted as a shelter for animals. In recent years, the church stood completely abandoned and was partly in ruins. Several men from the Radonjić family had largely re-built it, covered it with a new roof, and had obtained a rather expensive iconostas so that it could now accommodate any Orthodox Christian rite.

On August 27, 2017, the foundation planned to inaugurate the commemorative centre. This was intended as a gathering of the relatives of the Radonjić lineage, some of whom would be travelling from abroad. Some people would be giving speeches. The priest would hold a mass in the freshly refurbished church. The foundation printed celebratory texts that were to be distributed to the guests, and they had sent invitations to the guests from within and outside the immediate circle of relatives. According to official regulations, they also informed the authorities that the event and the church mass would take place.

When the guests arrived on the Sunday morning of the celebration, they found a group of policemen blocking their way so that guests had no access to the buildings where the ceremony was to take place. The policemen did not give any coherent explanation, but it was clear that they had received strict orders to prevent the event from taking place. The bewildered organisers had no other option but to cancel the event.

Later on, the organisers wrote to the police asking for official clarification of the situation. The police explained that they had only tried to prevent conflicts between rivalling religious communities. A short explanation is in order. Until 1918, the Montenegrin Orthodox Church was autocephalous: an independent branch of the Orthodox Church. With the entry of Montenegro into the Kingdom of Serbs, Croats and Slovenes, the 
Montenegrin Church was unified with the Serbian Orthodox Church. When a separatist movement began again in the early 1990s, some Montenegrins began advocating the separation of the Montenegrin Orthodox Church from the Serbian Orthodox Patriarchate. Although initially enjoying some political support and surviving throughout the 1990s, this faction failed to gain official recognition and more importantly-recognition of their claims to the church buildings. Eventually in 2001, the Montenegrin Orothodox Church was officially registered in Montenegro as a non-governmental organisation, thus obtaining legal right to conduct religious rites, but it remained unrecognised by the rest of the Orthodox Church. Nevertheless, the Montenegrin Orthodox Church asserts that it is the sole legitimate heir of the old autocephalous church that existed in the country until 1918. The church and its supporters have laid claim to all the church buildings, including monasteries and small chapels. Current usage of the buildings by the Serbian Orthodox Church, they maintain, is only a result of the Serbian occupation. As it happened, at least part of the Radonjić family were supporters of the Montenegrin Orthodox Church, and the priest that they invited was also from that organisation.

In the above-mentioned letter, the police answered that they had intervened because there was supposed to be another meeting of the Serbian Orthodox Church 'at the same time and in the same place'. The police had intervened only in order to prevent an open conflict, because both sides had declared that they anticipated a large number of participants, and according to the letter, the police had previous bad experiences from similar situations. In fact, no Serbian Orthodox Church representatives appeared on that Sunday morning on $27^{\text {th }}$ of August 2017.
The phantoms, which had seemed to me to be just figments of someone's imagination, and which somehow provided some spiritual comfort to the people in this village, had suddenly taken form as a clear, physical force: the police forces forbidding the commemorative event. The Serbian Orthodox Church had shown no interest in the chapel of St. Archangel until it had been restored by the local family. Nor did it show any interest or make its presence known during other church holidays (for instance during Easter of 2017, when I was there). Now, however, the Serbian Church had reportedly taken a sudden interest in organising a large gathering on this particular Sunday morning. The people from the Radonjić family were quite convinced that the Serbian Orthodox Church had no intention of organizing any competing event, as the police claimed and that it was all a pretext intended to prevent the opening of the commemorative centre.

The phantom armies of the guvernadur Vukolaj Radonjić, who were important for the contemporary relatives of the Radonjić lineage, were not only symbolic and not only related to the local family branch that wanted to celebrate their cultural heritage. The celebration of guvernadur was apparently a threat to someone else. The opening of the commemorative centre which brought together the descendants of the guvernadur Vukolaj Radonjić was obviously seen by others as threatening enough to ban the event using an organised police presence. I do not know how much of this threat was linked to the phantom of guvernadur Radonjić. The ban could also have been a move to clamp down on a potential oppositional gathering. Nevertheless, the fantasies somehow coagulated, and the events of 1832 seemingly sprang into reality in this phantom rebellion. Whether from the point of view of the organisers of the event or from 
those who initiated the ban, the presence of phantoms was crucial. The organisers walked in the shadow of guvernadur Radonjić. The police and those who initiated the ban acted under the influence of this perceived threat-whether it was guvernadur himself or the growing contemporary political opposition does not change the story.

\section{PERFORMING WITH THE PHANTOMS}

Like other performances, the state performance is tied to the various individual performers. The Radonjićs had their own version which they tried to enact. In this performance, the state that they were trying to create though their activities was in opposition to another state which had been constructed with another vision in mind. However, this opposing version was also partly a result of their own imagination: it was a construction that they had attributed to the activities of the police, possibly in league with the Serbian Orthodox Church. According to this vision, the Radonjićs were carrying on the banner of the state that is open to Western integration and which is educated and enlightened. There is no reason to believe that their opponents did not think of themselves along similar lines. ${ }^{4}$

What emerges here is an image of the state that is fluid, a state that is the outcome of refined and subtle manoeuvres using various kinds of images and performances. From the point of view of Radonjićs, Njegoš, although an undeniably talented poet, was not a particularly good ruler. That their ancestor fought against him and suffered by his hand provided additional justification for them to legitimate their position in the contemporary political field.

This story, however, is hardly one about simple path-dependency, where one part of the village (those who trace their ancestry to Njegoš) support one version of the state while those who trace their ancestry to guvernadur Radonjić support another. It is a matter of rather pragmatic choice in which the phantoms of the long-dead ancestors or neighbours or other people are recruited in order to fight a contemporary struggle. As a result, the stories and histories of events long past, in which none of the people involved have taken part themselves, become imbued with meanings according to the vision that one has of oneself vis-à-vis the rest of the society, or what one imagines to be the state. The myth of guvernadura and the dynasty of Radonjićs provides an explanation for the current oppositional stance of the part of the family which was involved in the opening of the commemorative centre. The Radonjićs do not support the ruling coalition. They would support an opposition party if there were one worth supporting at the moment. At the same time, they are undeniably nationalistically oriented, fiercely opposed to any attempts to rule the nation from outside, particularly if that 'outside' means Russia or Serbia, both of which they interpret as having imperialist aspirations regarding Montenegro. During the times of guvernadura, their ancestor Vukolaj, so the story goes, took a similar stand against outside interference. Hence, the struggle today is no different from the struggle then. The phantom rebellion is the same as the actual one.

The problem, however, is that the reality of 'actual rebellion' today turned out to be somewhat ambivalent. The state that is emerging from these performances-in between the conflicting stories, the contested buildings, the restored ruins, the police, the opposition, the various families gathering, and the letters being exchanged-is multi-dimensional to say the least. The state here does not appear to be the same in the eyes of the people who were 
involved in the conflict on that Sunday morning in August 2017. What happened that day could be explained by the events of 1832; there were some unmistakable parallels, but the official explanation of the ban made no mention of the past. Nor did it mention another possible phantom-that of a gathering of contemporary political opponents to the current Montenegrin political regime. Instead, the danger of a rather mundane clash with another mass-meeting was cited as the reason why police had to intervene. Order had to be kept, and violent riots had to be prevented. As it turned out, however, there was no competing mass-gathering being held at the same time. That, too, was a phantom. From the Radonjićs' viewpoint, the state power was being abused by the elite groups (which were not clearly specified), who, as it seems, resembled the path taken by Njegoš almost two centuries earlier.

These events could be interpreted as an example of path dependency, where participants simply pursue strategies and stick to actions predetermined by their predecessors and continue performances that they have internalised since childhood. Instead, based on my conversations with the representatives of the Radnonjć family, I see their activities as a pragmatic action by which they perform a state of their choice-a state that in their view is more suited to their vision of how the state should be run and positioned in the international community. Invoking their histories then become devices by which the Radonjićs legitimise their imagined moral superiority in contrast with competing, dominant versions of history and state performances.

\section{THE STATE AS A PHANTOM}

So far, I have paid little attention to the concept of 'phantom' although it certainly is central in this discussion. My own image of the phantom is more visual, almost ghost-like. The positivist sceptic would emphasise the illusory component of the phantom. However, European concepts of the ghost or spirit are related to dualistic, Cartesian or multiple components of reality. A ghost or a phantom is thus different from a vision or hallucination because it is not just a product of one's imagination. In this sense, what I am describing differs from the 'ghosts and shadows' that Sorenson and Matsouka (2001) identify as playing an important role in contemporary states and nations. In their view ghosts and shadows are a pure product of imagination that has no concrete relation to reality, but only affects reality. My phantom is more similar to Lippmann's when he describes the 'American public' as a phantom because it is, according to him, 'an abstraction' (Lippmann 1993: 67).

The concept of phantom is also used in medicine. When a person has lost an arm or a leg, it is not uncommon to continue having a realistic sensation of the limb; this phantom limb might continue hurting or one could move it just like any other existing one. The phantom limb is subjectively there, but objectively gone (see for instance Melzack 1992; Millonig 2011).

Nevertheless, in most cases a phantom limb is not entirely without the trace of reality. The limb was once actually there, what is left is the sense of the limb as realistic as if it were actually there or perhaps even more so:

Their vivid sensory qualities and precise location in space-especially at firstmake the limbs seem so lifelike that a patient may try to step off a bed onto a phantom foot or lift a cup with a phantom hand. The phantom, in fact, may seem more substantial than an actual limb, particularly if it hurts (Melzack 1992: 120). 
Olma (2018) uses the concept of 'phantom pain' in order to describe how people in Tashkent feel about trees that once used to be in the city, but have been cut down.

The phantoms that I have described here in relation to the state are not entirely like such phantom limbs or trees. On the one hand, it seems like a fantasy because the guvernadur Radonjić and the dynasty of Petrović Njegoš are long gone. The events to which all the involved people refer are stories from the past. On the other hand, these narratives are the very substance that cause all the involved actors to mobilize and act in the particular manner they do. The phantom limbs are of course a figment of brain malfunction that fails to realise the sudden absence of the limb and continues producing sensations which lure the individual into a false sense that the limb still exists. Failure to convince the brain of the contrary (i.e. that the limb is not actually there) will inevitably lead to unfortunate accidents and perhaps further trauma.

The phantoms such as guvernadur Radonjić and Njegoš are of an entirely different order because they inhabit the same space as all the other elements of social life. As argued by Bloch, the imagination of the world 'as it is', cannot be separated from the 'other worlds' or the parts of the world that are constructed by fantasy (Bloch 2013). However, these worlds and the degree of belief in one or another combination of what is and what is not, vary (Graeber 2015). Thus, the 'phantom rebellion' may or may not be an actual rebellion, depending on what version of the link between then and now one subscribes to. The Radonjićs of today are transcendentally (to use Bloch's terminology) merged with the past. Whether this was interpreted in the terms described by Rovinski in 1881 (see the quote above) or the explanation they themselves would give, was a matter of choice.
Along with fantasy and imagination ghosts, spectres and phantoms have had a place in scholarly thinking about the state. In her review article of the anthropology of the state, Aretxaga (2003: 401-404) dedicates a section on the state as a fantasy or fetish (2003: 401-404). However, for her, the link between the state and fantasy or phantom is embodied by haunting and fear. Phantoms, spectres and fantasies emerge in relation to state terror, criminality, "phantom states' and various fears: 'It is in the act of killing, kidnapping, disappearances, and imprisonment that the state materializes as a powerful spectral reality' (Aretxaga 2003: 402). However, Aretxaga notes that 'it is not only the people who imagine the state but also the state itself in its multiple incarnations that has, and enacts, its own fantasies'(Aretxaga 2003: 399). ${ }^{5}$ As a result, people in all manifestations of the state may be haunted by the terrors of the phantoms that they associate with other groups (e.g. policemen fear spectres of terrorism) (Aretxaga 2003: 402). Similarly Goldstein (2012:81) reflects on Derrida and his hauntology, emphasising the danger that may stem from the state. Yet the phantom or ghost may refer also to entities that are not actually present and therefore feared (Goldstein 2012: 83). Thus, in Bolivia, Goldstein describes a Bolivian phantom state (because it is not there); nevertheless, both state representatives and citizens are provoked by phantoms, such as fantasy-inflated beings like the thief ratero into either fear or aggression.

Gordon (2008: 126) views social life as being permeated by ghosts and phantoms. While I subscribe to her definition of the ghost, I attribute more real substance to the relations between phantoms and people. In Gordon's optic, people are haunted by ghosts, who demand their attention, leaving people otherwise rather passive. However, as we can see from my ethnographic examples, the interaction 
between phantoms and people is much more cooperative.

In contrast to Aretxaga and other authors who emphasise the fearful aspects of phantoms, I argue that phantoms can also produce reassurance and encouragement. Phantoms can be threats or allies. The same phantom can be frightening and reassuring. Thus, Aretxaga (2003: 406) interprets Althusser's policeman's 'Hey, you!' as gaining strength from the policeman's 'spectral other'. I arguet that while for the supposed violator of a law this 'spectral other' is a source of fear, for the policeman and those who seek his or her help, the same 'spectral other' is reassuring.

All the sides that participated in the events of the 'phantom rebellion' acted in association with phantoms. However, a framework that operates with a strict division between the state and citizens (as do many scholars, such as Aretxaga or Gordon), cannot grasp the complexity of people's relations with phantoms. The 'phantom rebellion' (like most rebellions) was not a resistance or rebellion against the state as such, but only against a particular version and interpretation of the state. Thus, the Radonjićs employed phantoms that helped them perform the kind of state that they imagined would be most appropriate according to their vision. So did the other participants as well.

Instead of being a past presence that haunts people in the present, the phantom also has a formative function. Because of this, the phantom is never simply a fearful, threatening fantasy. It is part of the body of knowledge and affections on the basis of which all the involved actors build their action. As in the case with missing limbs (or limbs that have never been there), the phantom can cause actual pain, it can make people move and act on the assumption that the phantom is intensely present (see also Myrttinen 2013). However, in comparison to the physical body, the realm of state and society is much more ethereal, if not completely so.

If we assume that the state is created through performances, we can see that the phantoms are part and parcel of these performative activities. However, whatever is created as a result is not a uniform monolith. It is not a single solid entity but a fluid amalgam, a multiplicity of perspectives, many of which are contradictory. The state is thus one type of entity for Željko, another for Milan and yet another for the policeman who was sent on some phantom mission to uphold the public order and prevent a clash of religious opponents, a clash which itself was just another phantom.

\section{CONCLUSION}

I began this article with an ethnographic vignette in which $\mathrm{I}$ was introduced to the historical guvernadur Vukolaj Radonjić, in whose house I was apparently residing. The vignette started with Milan and me erecting defences against a potential invading army of flies and other insects, an army that eventually never materialized but nevertheless caused a real action on behalf of both of us. I treat this story as a sign of what would later happen in the realm of state, when the group of relatives and descendants of Vukolaj Radonjić sought to celebrate the opening of the commemorative centre. Instead of this being simply an internal family event, the ceremony provoked the intervention of the police force and apparently re-awakened an old narrative of confrontation which had genuine present-day political consequences. It seemed that some kind of rebellion was in progress, but this rebellion, too, was entirely a phantom. However, the phantom nature of the event does not diminish its significance, especially when one tries, as I have done here, to understand how a state is 
performed. In the process of state performance, such phantoms are not only irregular and perhaps alternative outcomes of people's creative imagination; they are the very stuff of state performance, the script, so to speak. At the same time, this clash of phantoms demonstrates the rather wide range of freedom involved in the relation between the performance and the phantom. State performance is not simply a process whereby the subject is drawn into and indoctrinated by all different means possible (as Althusser or Foucault might lead us to think); nor is this a process whereby the individual succumbs to phantom agents. Rather, people actively choose which phantoms to align themselves with and against which to stand.

\section{EPILOGUE: THE PHANTOM EYE}

Željko, with the help of his nephew, had been working for several days. The men needed to cut an opening in a wall and make a door there. If this could be done, their enterprise would comply with EU food safety regulations, perhaps helping them to get a foot in the door of the EU market for their pršut [smoked ham] production. The task was difficult, because the building was made of large limestone blocks, perhaps the same that were once part of the destroyed house of guvernadur Vukolaj Radonjić. During a break in the work, I sat down with Željko and chatted. 'It is my grandfather's and grandmother's picture that you have in your house,' Željko said. 'He was a giant, maybe about two meters high. But she was tiny.'

I was surprised. 'How come?', I asked, 'they look about the same height on the picture'

'That's because she is standing next to him while he is sitting on a chair. And one of his eyes is missing, did you notice? [no, I had not, both looked right where they had to be]. Yes, he lost one when a bullet ricocheted from a stone during a [celebratory shooting of pistols at] a wedding.'

Later on, I took another look at the picture trying to figure out which eye was the fake one. But I was unable to find any difference. Perhaps it was a convincing phantom eye, perhaps the whole story was a phantom, just like the spiders and myriads of flies we were guarding the house from, the phantom insects that never came.

\section{NOTES}

1 Names of persons (except those of public officials) have been changed. The family names and the name of the village have not been changed because the story is intimately linked to the place and the lineages. The general outlines of the story are described in Montenegrin mass media (see Pobjeda, August 28, 2017: 11), therefore further anonymisation seems to be unnecessary.

2 Bieber's article covers the period up to 2003. Regarding political leadership, little has changed since.

3 Without going too much into details of contemporary Montenegrin politics, it is important to note, that although Radonjićs drew some parallels between Njegoš and Đukanović, the latter is a stern advocate of European integration. Therefore in this sense Radonjićs were not in complete opposition to Đukanović's policies. Nevertheless, they still were in opposition to another large political stratum in Montenegro who saw closer integration with Serbia and Russia as possible and beneficial.

4 The image of being "educated and enlightened' is used in different versions of this narrative when Montenegrins talk about the roots of their statehood. Vladika Petar II Petrović Njegoš is praised not so much for his battlefield achievements or because he managed to subdue opponents like guvernadur Vukolaj Radonjić, but especially because of his literary genius and philosophical thoughts. Moreover, the orientation towards the West and the EU has been the unequivocally pursued official policy of the Montenegrin government and of prime minister/President Milo Đukanović.

5 The language used by Aretxaga here and on 
numerous other instances in her article depicts a state that can act, think, believe and feel. Here the state fears.

i Note on funding: The empirical data for this article was collected during my fieldwork which was part of the Horizon 2020 project 'Closing the Gap between Formal and Informal Institutions in the Balkans' (INFORM), Grant Agreement no. 693537. The analysis and the conceptual work was carried out as part of the Latvian Research Council project 'State Performance and Biosocial Relatedness' lzp-2018/2-0070

\section{REFERENCES}

Abrams, Philip 2006. Notes on the Difficulty of Studying the State. In Aradhana Sharma and Akhil Gupta (eds). The Anthropology of State. A Reader. Oxford: Blackwell Publishing.

Aretxaga, Begoña 2003. Maddening States. Annual Review of Anthropology 32 (1): 393-410. https://doi. org/10.1146/annurev.anthro.32.061002.093341.

Benjamin, Braude and Bernard Lewis 1981. Chistians and Jews in the Ottoman Empire. New York: Holmes and Meier Publishers.

Beyer,Judith 2014. 'There Is This Law...' Performing the State in the Kyrgyz Courts of Elders. In Madeleine Reeves, Johan Rasanayagam, and Judith Beyer (eds). Ethnographies of the State in Central Asia: Performing Politics. Bloomington: Indiana University Press.

Bieber, Florian 2003. Montenegrin Politics since the Disintegration of Yugoslavia. In Florian Bieber (ed.) Montenegro in Transition. Problems of Identity and Statehood. Baden-Baden: Nomos Verlagsgesellschaft.

Bissenova, Alima 2014. The Master Plan of Astana: Between the 'Art of Government' and the 'Art of Being Global'. In Madeleine Reeves, Johan Rasanayagam, and Judith Beyer (eds). Ethnographies of the State in Central Asia: Performing Politics. Bloomington: Indiana University Press.

Bloch, Maurice 2013. Why Religion Is Nothing Special but Is Central. In In and out of Each Other's Bodies: Theory of Mind, Evolution, Truth, and the Nature of the Social. Boulder, CO: Paradigm Publishers.
Bobick, Michael 2014. Separatism Redux. Anthropology Today 30 (3): 3-8.

https://doi.org/10.1111/1467-8322.12108.

Butler, Judith 2006. Gender Trouble: Feminism and the Subversion of Identity. London: Routledge.

Das, Veena and Poole, Deborah 2004. State and Its Margins: Comparative Ethnographies. In Veena Das and Deborah Poole (eds). Anthropology in the Margins of the State. Oxford: Oxford University Press.

Derrida, Jacques 1994. Specters of Marx: The State of the Debt, the Work of Mourning and the New International. London: Routledge.

Goldstein, Daniel M. 2012. Outlawed. Between Security and Rights in a Bolivian City. Durham: Duke University Press.

https://doi.org/10.1215/9780822395607.

Gordon, Avery F. 2008. Ghostly Matters: Haunting and the Sociological Imagination. Minneapolis: University of Minnesota Press.

Graeber, David 2015. Radical Alterity Is Just Another Way of Saying 'Reality': A Reply to Eduardo Viveiros de Castro. HAU: Journal of Ethnographic Theory 5 (2): 1-41. https://doi.org/10.14318/hau5.2.003.

Gregović, Savo and Veliša Kadić 2013. Kako Je Srušen Njegošev Zavet. www.novosti.rs. http://www. novosti.rs/vesti/naslovna/reportaze/aktuelno.293. html:442814-Kako-je-srusen-Njegosev-zavet. <accessed 1 March 2019>

Ismailbekova, Aksana 2014. Performing Democracy: State-Making through Patronage in Kyrgyzstan. In Madeleine Reeves, Johan Rasanayagam, and Judith Beyer (eds). Ethnographies of the State in Central Asia: Performing Politics. Bloomington: Indiana University Press, 78-98.

Ivy, Merylin 1995. Discourses of the Vanishing. Modernity, Phantasm, Japan. Chicago: The University of Chicago Press.

https://doi.org/10.7208/

chicago/9780226388342.001.0001.

Jansen, Stef 2014. Hope For/Against the State: Gridding in a Besieged Sarajevo Suburb. Ethnos 79 (2): 238-260.

https://doi.org/10.1080/00141844.2012.743469. 
Jusionyte, Ieva 2015. States of Camouflage. Cultural Anthropology 30 (1): 113-138.

https://doi.org/10.14506/ca30.1.07.

Laszczkowski, Mateusz 2014. State Building(s): Built Forms, Materiality, and the State in Astana. In Madeleine Reeves, Johan Rasanayagam, and Judith Beyer (eds) Ethnographies of the State in Central Asia: Performing Politics. Bloomington: Indiana University Press.

Lippmann, Walter 1993. The Phantom Public. New Brunswick: Transaction Publishers.

Matsuoka, Atsuko and Sorenson, John 2001. Ghosts and Shadows. Toronto: University of Toronto Press. https://doi.org/10.3138/9781442675322.

Melzack, Ronald 1992. Phantom Limbs. Scientific American 266 (0036-8733 (Print)): 120-126.

https://doi.org/10.1038/scientificamerican0492-120.

Millonig, Alban 2011. Phantom Limbs - Or Phantoms of Phantom Limbs? Cortex 47 (9): 10631064.

http://dx.doi.org/10.1016/j.cortex.2010.12.004.

Morrison, Kenneth 2009. Montenegro a Modern History. London: I.B. Tauris.

Mühlfried, Florian 2014. Being a State and States of Being in Highland Georgia. Oxford: Berghahn Books.

Myrttinen, Henri 2013. Phantom Menaces: The Politics of Rumour, Securitisation and Masculine Identities in the Shadows of the Ninjas. Asia Pacific Journal of Anthropology 14 (5): 471-485.

http://dx.doi.org/10.1080/14442213.2013.821154.

Navaro-Yashin, Yael 2002. Faces of the State: Secularism and Public Life in Turkey. Princeton: Princeton University Press.

https://doi.org/10.1515/9780691214283.
Olma, Nikolaos 2018. Enacting Memoryscapes: Urban Assemblages and Embodied Memory. PhD Thesis. Københavns Universitet. https://curis.ku.dk/ portal/files/199639433/Ph.d._afhandling_2018_ Olma.PDF. <accessed 14 September 2020>

Radcliffe-Brown, Alfred Reginald 1987. Preface. Edward Evan Evans-Pritchard and Meyer Fortes (eds). African political systems. London: Oxford University Press.

Rovinski, Pavel [Ровинский, Павел] 1881. Ньгуши. Русская Мысль 2 (1): 364-390.

Radonjić, Djoko 2017. Osveštanje Crkve Guvernadura Radonjića Sveti Arhanđel Mihailo.

Taussig, Michael 1992. The Nervous System. New York: Routledge.

Taussig, Michael 1997. The Magic of the State. New York: Routledge.

Yurchak, Alexei 2006. Everything Was Forever, Until It Was No More. Princeton: Princeton University Press.

Žižek, Slavoj 2008. The Sublime Object of Ideology. London: Verso.

KLĀVS SEDLENIEKS

ASSISTANT PROFESSOR

DEPARTMENT OF COMMUNICATION

STUDIES

RİGA STRADIN̦Š UNIVERSITY

Klavs.Sedlenieks@rsu.lv 